\title{
Light-Trap Catch of European Corn-Borer (Ostrinia Nubilalis Hbn.) in Connection with the Sunspot Numbers in Hungary between Years 1959-2006
}

\author{
László Nowinszky*, János Puskás and Miklós Kiss \\ Eotvos Lorand University, Hungary
}

Submission: February 15, 2018; Published: March 12, 2018

*Corresponding author: László Nowinszky, Eotvos Lorand University, Savaria Campus Savaria Science Centre, 9700 Szombathely Károlyi Gáspár Square 4. Hungary, Email: lnowinszky@gmail.com

Abstract

The study examined the light-trap catch of European Corn-borer (Ostrinia nubilalis Hübner) in connection with the sunspot numbers. The catching data of European Corn-borer (Ostrinia nubilalis Hbn, Lepidoptera: Crambidae) were taken from the light-trap registers of the Hungarian Light-trap Network. During these years (between 1959 and 2006), 321,795 moths were caught by the 131 light-traps. Our results demonstrate it is favourable for the Ostrinia nubilalis $\mathrm{Hbn}$. if the number of sunspots is the same as the average. Both the smaller and the higher number of sunspots reduce the flying activity.

Keywords: Sunspots; Light-trap; Ostrinia nubilalis

\section{Introduction}

The Sun's activity is the common name of the larger, local disturbances in the Sun's radiation. Electromagnetic and corpuscular radiation coming from the Sun causes changes in geophysical parameters on Earth (The coincidence or delay of the appearance of a terrestrial phenomenon depends on whether it is caused by electromagnetic or corpuscular radiation).

Such events may be the aurora polaris, the change of the ionospheres and the magnetosphere of the upper atmosphere, the formation of weather fronts, and the sudden alteration of the characteristics of the earth's magnetism. These can be followed by changes in the biosphere's phenomena.

The solar activity, such as solar flares, may cause irregular departures from typical climatic conditions. Blunck \& Wilbert [1] assumes that insect gradations may be related to solar activity.

Polgár [2] found that the dry and the inland water years coincide with the sunspot with maxima or minima.

Manninger [3] made observations on the gradation of harmful insects during a long period. There was a connection between overproduction and dry and rainy periods that are related to the activity of the Sun. It has been shown that in the second half of the dry season there was gradation for droughtloving species, while at other times the gradation occurred in wet habitats for moisture-loving species. Richmond [4] suggests the sunspots affect the weather, which in turn affects the abundance of insects. However, Hemlock Looper (Lambdina fiscellaria Guenée) abundance in British Columbia was apparently not related to the sunspot cycle.

Klimetzek [5] investigated pest gradations between 1810 and 1970. He found in these investigations that high gradation occurs in those cases, when the minimum and maximum values of sunspots can be counted. Later a lot of researchers have created an index number that takes into account the intensity of the flares and the duration of their existence.

The solar activity typified by the use of different indices. The solar activity can show all the information about the Sun's surface got them with several way. The most important one is the appearance of sunspots, which has been continuously examined since the $18^{\text {th }}$ century phenomenon. The sunspots can be seen on the sun-facing hemisphere of the Earth. Their appearance and their strength frequency are about 11.2 years. The generally accepted index-number of their observable quantity is the Wolf- 
type relative number (RW), which is calculated according to the following formula:

$$
\mathrm{R}_{\mathrm{w}}=\text { constant }(10 \mathrm{~g}+\mathrm{f})
$$

Where: $g=$ the number of observed sunspot groups

$\mathrm{f}=$ the number of all sunspots

Features of instruments used in detection determine the value of constant. After the selection of instruments sunspot relative number determined in any of the world's solar physics observatory can be reduced onto a uniform scale.

The use of Wolf's relative numbers has been significant progress in the meteorological researches in the second half of the $20^{\text {th }}$ century. Similarly, significant results were obtained in studies of Wolf's relative numbers and the relationship between plant pathogens. Details of these could not be our goal, but we refer to a previous study of ours [6], in which we have a detailed overview about this. Some researchers found a contact between some pests and the solar activity.

Martinek [7] concluded that in a large number of appearance of European Pine Sawfly (Neodiprion sertifer Geoffroy) can be found in every 11 year when there is maximum of sunspots. Benkevich [8-11] studied several cyclic solar activities and gradations of Gipsy Moth (Lymantria dispar L.). Based on data from long periods, he found that in the vast areas of the Soviet Union they are related to Wolf's relative numbers. Kleczek [12] was the first researcher, who used first time the Q-index to demonstrate the daily flare activity. This daily flare activity is specific characteristic in the whole day.

$$
\mathrm{Q}=(\mathrm{i} \times \mathrm{t})
$$

where $\mathrm{i}=$ flare intensity, $\mathrm{t}=$ the time length of its existence.

Kleczek thought this connection show about the whole energy which arises from the flares. In this relation "i" shows the intensity on scale of importance and " $t$ " shows the period (in minutes) of the flare. Some researchers used the method of Kleczek in connection with flare activity which is determined for every day $[12,13]$.

Turkish astronomers [14] characterised the daily flare activity for several decades. They used for this characteristic the Q-index. This index shows the significance of flares also by their duration Ataç [15] and Ataç \& Özgüç [16].

The Q-index data are available to researchers from 1966. In addition to our own studies [17-22] other researchers did not make any examinations dealing with the connection between entomology and Q-index data. A Hungarian researcher, Örményi [23] also calculated and published the "Flare Activity Numbers" based on similar theoretical principles as the Q-index for the period of 1957-1961.

Waldmeier [24] has been executing studies on the frequency, extent ad intensity of flares. He proposed a new method for the definition of the intensity of chromospheric flares. This was based on brightness measurements, taking into account the average intensity of the flares. As a result of these investigations, a new scale of intensities has been established namely classification by Waldmeier: 0.6, 1.0 and 2.0.

For the scale of simplifying the calculations, Örményi [23] has adopted the proportions $1.0: 2.0: 4.0$ for the characterization of the intensities of various flares. An index for chromospheric $\mathrm{H} \alpha$ flare activity is introduced by Örményi [23]. This procedure is expressed by the formula:

$$
\text { FAN }=\frac{1}{1440} \frac{\Sigma}{n} 1_{n} \Delta t_{n}
$$

Where: FAN=Flare Activity Number

I=intensity of the flare (one of the values 1, 2 or 4)

$\mathrm{n}=$ indicates the serial number of a flare occurring on a given day

$\Delta \mathrm{t}_{\mathrm{n}}=$ the duration of the given flare (minutes)

There were established two light trap networks (agricultural and the other at research institutes) till 1958 which were in operation uniformly with Jermy-type light-traps. From 1961 some light-traps of forestry already were in operation.

Nowinszky \& Puskás [25] examined the light trapped three moth (Lepidoptera) species from the data of agricultural observation stations in connection with the FAN numbers. It is found that their results proved that "Flare activity numbers" could be used for entomological researches.

\section{Material}

The catching data of European Corn-borer (Ostrinia nubilalis Hbn, Lepidoptera: Crambidae) were taken from the light-trap registers of the Hungarian Light-trap Network. During these years (Between 1959 and 2006), 321,795 moths were caught by the 131 light-traps. Of course, not all light-traps operated full years, but some of them were ceased, others sited later. This many moths were trapping in 6,635 nights. However, because more light-trap worked during one night, we could work up 80,773 observation data.

The sunspot data were taken from the World Data Center SILSO, Royal Observatory of Belgium, Brussels.

\section{Methods}

The daily values of the sunspot numbers showed significant differences in the various years therefore we looked into the question of whether sunspot numbers that show significant differences from one year to the other modifies the number of the caught of examined moths collected in the different years. Three classes were formed from the years in accordance to the average sunspot numbers were in swarming period of less than 30 (19 years), between $30-100$ ( 7 years), or was there more than 100 (20 years). 
The individual number is not the same in the different years and regions concerning to the same species. Because of this, relative catching $(\mathrm{RC})$ values were calculated from number of caught individuals. RC value means the sampling time unit (generally it is one night) and the average individual number in unit time of sampling [26].

Within the three groups, we made divisions using Sturges' method $[27,28]$. Finally, we averaged within groups the sunspot and relative catch data pairs. In the figures are plotted the results and in them were shown the confidence intervals.

\section{Results and Discussion}

Our results demonstrate in all three groups that both the low and high values of sunspot depress the flying activity of European Corn-borer (Ostrinia nubilalis Hbn.). In contrast, the moderate values of sunspot can rise in flying activity and of course together with the caught individuals (Figure $1 \& 2$ ).

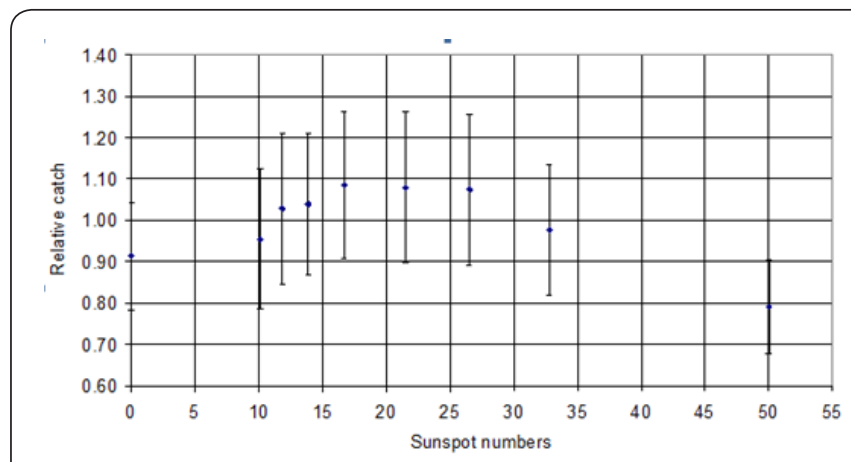

Figure 1: Light-trap catch of European corn-borer (Ostrinia nubilalis hubner) In connection with the sunspot numbers (Average values in summer months of sunspot numbers are lowerthan 30).

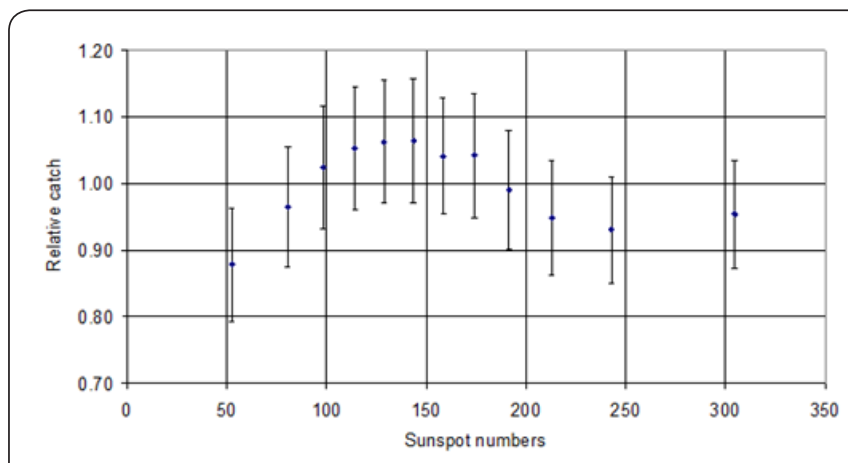

Figure 2: Light-trap catch of European corn-borer (Ostrinia nubilalis hubner) In connection with the sunspot numbers (Average values in summer months of sunspot numbers are higher than 100).

It seems, therefore, that during the drawing periods it is favourable for this species if the number of sunspots is the same as the average. Both the smaller and the higher number of sunspots reduce the flying activity. We do not know exactly why. However, we assume that the influence of solar activity is related to a change in terrestrial weather conditions and geomagnetic disturbances or other environmental factors. These all affect the life phenomena of insects, including their flying activity.

\section{References}

1. Blunck H, Wilbert H (1962) Der Baumweisling Aporia crataegi L. (Lep, Pieridae) und sein Massenwechsel Z ang Ent 50(2): 166-221.

2. Polgár Gy (1966) Connection with the solar activity and inland waters (in Hungarian) Vízügyi Közlöny 1: 130-132.

3. Manninger GA (1975) Relationship between dry and wet seasons with field pests (in Hungarian). Növényvédelem 11 (11): 506-507.

4. Richmond HA (1938) Some notes on the periodicities of certain insects in relation to the sun spot cycle. Proc Ent Soc British Columbia 34: 4954.

5. Klimetzek D (1976) Insektenvermehrungen und Sonnenflecken. Forstwissenschaftliches Centralblatt Cbl 95(1): 226-238.

6. Nowinszky L, Tóth Gy (1987) The effect of cosmic factors on light-trap catch of harmful insects (in Hungarian). Dissertation. Keszthely, p.123.

7. Martinek V (1972) Über die Möglichkeiten der langfristigen Prognose der Massen-vermehrung der Roten Kiefernbusch-horn-blattwespe (Neodiprion sertifer Geoffr.) und die Bedeutung ihrer. Proceedings of International Congress of Entomology, Moskau 1968(3): 58-70.

8. Benkevich VI (1968) Gypsy moth outbreaks in the European part of the USSR as related to solar activity fluctuations, atmospheric circulation, climate and weather conditions. In: Trudy Xlll Mezhdunarodnogo entomologicheskogo kongressa. Nauka, Moscow, pp. 14-15.

9. Benkevich VI (1984) Gypsy moth outbreaks in the European part of the USSR. (Massovyye poyavleniya nepamogo shelkopryada v Evropeyskoy chasti SSSR.) Nauka, Moscow, p. 143.

10. Benkevich VI (1988) Die Sterblichkeit der Raupen des Schwammspinners, Lymantria dispar L. (Lepidoptera, Liparidae) wegen Entomophagen und Krankheiten in Zusammenhang mit der Sonnenfleckenintensitat, dem Klima und dem Wetter. In: XI1 Mezhdunarodnyy simpozium po entomofaune Sredney Evropy. Kiev, 25-30 sentyabrya 1988. Tezisy dokladov. Naukova Dumka, Kiev, p. 23.

11. Benkevich VI (1990) The relationship between solar-climatic situations and outbreak of the gypsy moth, Lymantria dispar L. (Lepidoptera, Lymantriidae), in the Moscow Region over 120 years. Entomologicheskoye obozrenie 69(1): 3-13.

12. Kleczek J (1952) Catalogue de l'activite' des e'ruptions chromosphe'riques. Publications of Institute Centre of Astronomy No 22 Chechoslovakia, Prague. Institute Centre of Astronomy.

13. Knoška S, Petrásek J (1984) Chromosphere flare activity in solar cycle 20. Contributions of the Astronomical Observatory Skalnaté Pleso 12: 165-260.

14. Özguç A, Ataç T (1989) Periodic behaviour of solar flare index during solar cycles 20 and 21. Solar Physics 123(2): 357-365.

15. Ataç T, Özgüç A (1998) Flare index of solar cycle 22. Solar Physics 180(1-2): 397-407.

16. Ataç $\mathrm{T}$ (1987) Time variation of the flare index during the 21st solar cycle. Astrophysics and Space Science 135(1): 201-205.

17. Nowinszky L, Kiss O, Puskás J (2014) Light trapping of the caddisflies (Trichoptera) in Hungary (Central Europe) of different catches of the Q-index expressing the different intensities of solar flares. International Journal of Theoretical \& Applied Sciences. 6(2): 23-30.

18. Nowinszky L, PuskásJ (2001) Light-trapping of the European corn borer (Ostrinia nubilalis $\mathrm{Hbn}$.) at different values of the Q-index expressing the different intensities of solar flares. Acta Phytopathologica et Entomologica Hungarica 36(1-2): 201-205.

19. Nowinszky L, Puskás J (2013) The Light-trap Catch of Horse Chestnut Leaf Miner (Cameraria ohridella Deschka et Dimić, Lepidoptera: Gracillariidae) Depending on the Solar Activity Featured by Q-Index. 
International Journal of Geology, Agriculture and Environmental Sciences. 1(1): 32-35.

20. Ladányi M, Puskás J, Nowinszky L, Kiss O (2015) Modelling the light trap catch results of different caddisfly species under different intensities of solar flares. Int J Sustainable Agricultural Management and Informatics 1(4): 1-301.

21. Nowinszky L, Puskás J, Mészáros Z, Kúti Zs (2015) Light-trap catch of moth species of the Becse-type light trap depending on the solar activity featured by Q-index. Carib J Sci Tech 3: 752-760.

22. Puskás J, Nowinszky L, Barczikay G, Kúti Zs (2010) The pheromone trap catch of harmful moths in connection with solar activity featured by Q-index. Applied Ecology and Environmental Research 8(3): 261266.

23. Örményi I (1966) The relationship between geomagnetic activity and chromospheric Ha-flares. Acta Geodaetica, Geophysica et Montanistica
Acadaemia Scentica Hungarica 1(1-2): 121-136.

24. Waldmeier M (1940) Chromosphärische Eruptionen II. Zeitschrift für Astrophysik 20: 46-66.

25. Nowinszky L, Puskás J (2017) Light-trap catch of three moth (Lepidoptera) species at different values of the Flare Activity Numbers. eActa Naturalia Pannonica 14: 49-56.

26. Nowinszky L (2003) The Handbook of Light Trapping. Savaria University Press. 276.

27. Odor P, Iglói L (1987) An introduction to the sport's biometry (in Hungarian). ÁISH Tudományos Tanácsának Kiadása Budapest, p. 267.

Your next submission with Juniper Publishers will reach you the below assets

- Quality Editorial service

- Swift Peer Review

- Reprints availability

- E-prints Service

- Manuscript Podcast for convenient understanding

- Global attainment for your research

- Manuscript accessibility in different formats (Pdf, E-pub, Full Text, Audio)

- Unceasing customer service

Track the below URL for one-step submission https://juniperpublishers.com/online-submission.php 